\title{
Selective use of mangrove shorelines by snappers, grunts, and great barracuda
}

\author{
Craig H. Faunce ${ }^{1,3, *}$, Joseph E. Serafy ${ }^{1,2}$ \\ ${ }^{1}$ University of Miami, Rosenstiel School of Marine and Atmospheric Sciences, Division of Marine Biology and Fisheries, \\ 4600 Rickenbacker Causeway, Miami, Florida 33149, USA \\ ${ }^{2}$ National Oceanic and Atmospheric Administration, Southeast Fisheries Science Center, 75 Virginia Beach Drive, Miami,
} Florida 33149, USA

${ }^{3}$ Present address: National Oceanic and Atmospheric Administration, Alaska Fisheries Science Center, 7600 Sand Point Way NE, Seattle, Washington 98105, USA

\begin{abstract}
We examined seasonal utilization of $>500 \mathrm{~km}$ of mangrove shoreline within a subtropical continental system by Lutjanus griseus, L. apodus, Haemulon sciurus, H. parra, and Sphyraena barracuda over 2 consecutive years. Mangrove use by these species was examined in terms of frequency of occurrence, density (fish $60 \mathrm{~m}^{-2}$ ), concentration (density among samples where number of fish $\geq 1$ ), and selection $\left(\mathrm{H}_{0}\right.$ : habitat use = availability). All species exhibited either seasonal or spatial habitat selection. Mangrove shorelines closest to the reef tract (Keys) were used by snappers and grunts at much greater levels than their availability would suggest, whereas more inland and expansive mangrove shorelines were largely selected against. This selection pattern was evident year round for L. apodus, H. sciurus, and H. parra. In contrast, L. griseus preferred more inland mangroves during the dry season and Keys mangroves during the wet seasons. S. barracuda exhibited selection for Keys during the wet seasons and was the only species to exhibit non-selection (random) patterns among strata during the dry seasons. These results demonstrate that mangrove shorelines across broad spatial scales are not equivalent in their value as fish habitats, and that estimates of 'essential fish habitat' or 'nursery habitat' using total habitat area will grossly overestimate the amount of functional habitat used by these reef fishes.
\end{abstract}

KEY WORDS: Essential fish habitat · Habitat selection · Delta approach · Snapper · Grunt · Great barracuda $\cdot$ Mangroves

\section{INTRODUCTION}

Numerous fish species use shallow embayments during their juvenile and subadult stages before migrating to offshore habitats to spawn at maturity. In tropical and subtropical waters, these 'ontogenetic habitat shifters' (sensu Adams et al. 2006) include species of grouper (Serranidae), snapper (Lutjanidae), grunt (Haemulidae), and barracuda (Sphyraenidae), whose adult populations are targeted by fisheries around the globe. Bardach (1959) was among the first to suggest that populations of these reef fishes are enhanced by the presence of adjacent shallow water habitats such as seagrass beds and mangrove forests. A subsequent review by Parrish (1989) supported this notion in Atlantic and Caribbean waters, and added that establishing a relationship between juveniles in nursery habitats and adults in the final habitat would benefit from direct observational evidence of the effects of proximity of different habitat types and temporal stability over several years. Since then, species richness and total number of fishes collected adjacent to mangrove shorelines has been shown to decline with increasing inland distance from creek mouths and oceanic inlets worldwide. Recent studies within southeastern Florida (USA) illustrated that these trends are 
also evident for individual species belonging to the same functional group, i.e. reef fishes (Ley \& McIvor 2001, Serafy et al. 2003). Martino \& Able (2003) suggested that patterns in estuarine fish assemblage structure across large spatial scales (i.e. $>10 \mathrm{~km}$ ) are due to individual species responses to dominant environmental gradients. Following this logic, Faunce \& Serafy (2007) demonstrated that the distance between a sample location and an oceanic inlet (a proxy for crossshelf location) was primarily responsible for the separation of life-history stages of snappers and grunts within the mangrove shorelines of Biscayne Bay (southeastern Florida).

The above studies are limited in that most considered shoreline mangroves as homogenous units and all ignored size or area of mangrove patches between locations. Thus they offer limited information about the relative importance or value of one mangrove stand compared to another. Although mangroves are gaining increased recognition as habitats that can enhance growth and survival of immature reef fishes, few studies have been conducted at sufficient spatial and temporal scales to examine variation in reef fish utilization within this habitat type (e.g. Faunce \& Serafy 2006). These shortcomings are significant considering that the presence of mangrove-lined embayments enhances adult stocks of reef fishes in the western Atlantic (Dorenbosch et al. 2004, Mumby et al. 2004).

Resource selection studies, which compare the availability of a habitat type or patch to its use by animals, offer a means toward achieving habitat valuation under the assumption that animals will occupy sites that are best suited for their fitness (Thomas \& Taylor 2006). Under this assumption, when a particular habitat (or patch) is used by animals disproportionately relative to its availability (size), use is said to be selective (Manly et al. 1993). Mangrove availability may limit fish population distribution and size; in other aquatic systems, habitat limitation influences predation risk and foraging success in fishes (Dahlgren \& Eggleston 2000). While resource selection studies are common in terrestrial systems, until recently the utility of such studies toward understanding how fishes use different habitats has been largely ignored (Pollux et al. 2007), and formal tests of habitat use versus availability have not yet been applied to reef fish utilization of mangroves.

We investigated the use of mangrove shoreline habitats by snapper, grunt, and great barracuda in southeastern Florida. This study was conducted at a scale that encompasses prior study areas and considers mangroves as spatially-distinct units, and thus offers the opportunity to test the hypothesis that utilization of mangrove shorelines is a function of habitat availability. This hypothesis was tested by examining seasonal variation in several metrics and a standardized selectivity index on a species- and location-specific basis.

\section{MATERIALS AND METHODS}

Study area. This study was conducted along fringing mangrove shorelines of southeastern Florida that extend from southern Biscayne Bay (south and west of Key Biscayne) to northeastern Florida Bay (north and east of Russell Key and Tavernier Creek). Five mangrove shoreline types were identified based on their cross-shelf position, and each constituted a sampling stratum (h). Three mangrove shoreline types corresponded to those described by Lindeman et al. (1998): the mainland (ML), the western (leeward) shorelines of the Florida Keys (LK), and the eastern (windward) shorelines of the Keys (WK). Two additional shoreline types included the mangrove shorelines of islands within Biscayne and Florida Bays (IS), and 'landbridges' (LB) that connect portions of the ML and LK strata (Fig. 1a). Mean salinity increases, and variability decreases, with proximity to oceanic inlets located along the Florida Keys. Maps of mangrove shoreline coverage were generated by tracing geo-referenced color aerial photographs (Maptech; Photo Region 7.3) using geographical information system (GIS) software (ArcView GIS ver. 3.2). The resulting polygons were measured to provide a shoreline length estimate for each stratum $\left(L_{h}\right)$.

Fish sampling. Fishes were sampled from a visual survey, whereby an underwater observer identified, enumerated, and estimated the minimum, average, and maximum total length (TL) of fishes along a $30 \mathrm{~m}$ long $\times 2 \mathrm{~m}$ wide $\left(60 \mathrm{~m}^{2}\right)$ transect. Prior to sampling, observers were trained to accurately and rapidly identify and enumerate fishes using digital media. Accurate assessment of length underwater was subsequently achieved via repeated estimation of variouslysized plastic pipes following Bell et al. (1985). To ensure fishes could be effectively observed within each transect, horizontal visibility was determined using a vertically mounted Secchi disk and a measuring line prior to surveys. If visibility was less than $2 \mathrm{~m}$, the survey location was abandoned and a randomlyselected alternative location was visited. If no suitable alternative was available, locations were re-visited on a later date. All surveys were conducted between 09:00 and 17:00 $\mathrm{h}$ on dates that maximized hours of daytime flood tide. After fish sampling, a suite of environmental factors were measured (depth, salinity, temperature, $\mathrm{pH}$, tree height, prop roots $\mathrm{m}^{-2}$, epibiont diameters) and used in separate efforts to examine their influence on fish use of mangrove shorelines (Serafy et al. 2003, 2007, Faunce \& Serafy 2007). 

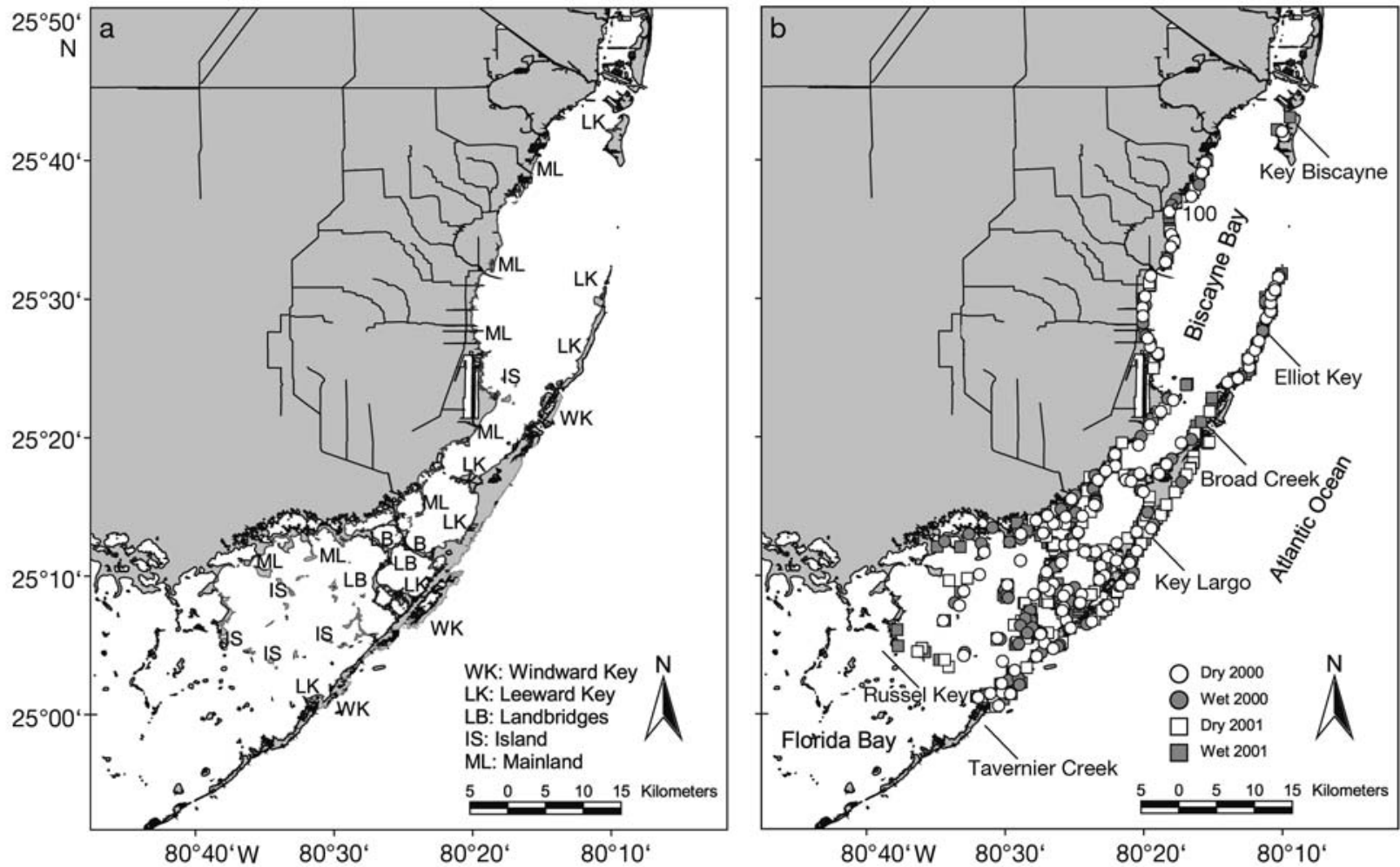

Fig. 1. Study domain and (a) the location of the 5 mangrove shoreline habitat types (strata) and (b) locations sampled

Sampling design. Visual surveys were conducted during the summer wet seasons (June to August), and the winter dry seasons (December to February) of 2000 and 2001. Samples were spatially allocated according to an iterative, stratified random sampling design detailed by Ault et al. (1999). During the dry and wet seasons of 2000, sampling effort was allocated among strata according to the weighting factor $w_{h}$ of each stratum:

$$
w_{h}=\frac{\left(\frac{L_{h}}{30}\right)}{N}
$$

where $L_{h}$ is the length (m) of mangrove fringe in a stratum, and $N$ is the total number of possible samples among all strata, or

$$
\sum_{h}\left(\frac{L_{h}}{30}\right)
$$

Because no sampling scheme will be optimal for all species of interest, density (inds. $\mathrm{m}^{-2}, D$ ) and variance $\left(s^{2}\right)$ information of the 5 focal species combined from 2000 were used to allocate sampling effort among strata for 2001 using an optimal (Neyman) allocation scheme:

$$
n_{h}=n \frac{w_{h} s_{h}}{\sum_{h} w_{h} s_{h}}
$$

$$
s_{h}^{2}=\frac{1}{n_{h}-1} \sum_{j=1}^{n_{h}}\left(D_{h j}-\overline{D_{h}}\right)^{2}
$$

where $n_{h}$ is the number of sampling transects $j$ in stratum $h, n$ is the total number of samples collected, $D_{h j}$ is the transect-specific density, $\bar{D}_{h}$ is the mean density within stratum $h$, and $s_{h}=\sqrt{s_{h}^{2}}$. The proportion of samples to be conducted within each stratum during 2001, $p$ (opt), was calculated by dividing $n_{h}$ by the total number of samples collected. An index of relative efficiency (IRE) was calculated by dividing the variance about the mean expected from a random survey, $\operatorname{var}\left[\bar{D}_{\text {ran }}\right]$ by the variance of density from a stratified design, $\bar{D}_{s t}$, or $\operatorname{var}\left[\bar{D}_{s t}\right]$, where

$$
\begin{aligned}
& \operatorname{var}\left[\bar{D}_{r a n}\right]= \\
& \frac{(N-n)}{n(N-1)}\left[\left(\frac{1}{N} \sum_{h} \frac{N_{h}}{n_{h}} \sum_{j}^{n_{h}} D_{h j}^{2}\right)-\left(\bar{D}_{s t}\right)^{2}+\operatorname{var}\left[\bar{D}_{s t}\right]\right]
\end{aligned}
$$

given

$$
\bar{D}_{s t}=\sum_{h} w_{h} \bar{D}_{h}
$$

and

$$
\operatorname{var}\left[\bar{D}_{s t}\right]=\sum_{h} \frac{w_{h}^{2} s_{h}^{2}}{n_{h}}-\sum_{h} \frac{w_{h} s_{h}^{2}}{N}
$$

given 
From this formulation IRE values $>1$ indicate a greater precision from stratification versus pure random sampling. Estimates of precision were obtained from the coefficient of variation (CV) calculated from $\operatorname{CV}\left[\bar{D}_{s t}\right]=\operatorname{var}\left[\bar{D}_{s t}\right]^{0.5} / \bar{D}_{s t}$.

Data treatment. At the species-specific level, count data may be dominated by zeros, reflecting a combination of patchiness in the environment, the distribution of the species concerned, and the inability of the observer to always detect animals when they are present (Jones et al. 2002). These factors can contribute to a large variance about mean density estimates. Fletcher et al. (2005) noted that mean fish density values may be viewed as the product of 2 components: (1) proportion of positive samples for the species in question (i.e. frequency of occurrence, hereafter referred to as 'occurrence'); and (2) the mean number of fish observed within non-zero samples (hereafter referred to as 'concentration'). Serafy et al. (2007) proposed that the analysis of occurrence and concentration data separate from density may be warranted, and termed these comparisons the 'delta approach.'

To determine if the delta approach was warranted, plots of $\ln (x+0.001)$-transformed data were made following Stefansson (1996) for 5 reef fishes common to the area: gray snapper Lutjanus griseus, schoolmaster L. apodus, bluestriped grunt Haemulon sciurus, sailor's choice H. parra, and great barracuda Sphyraena barracuda. For each reef species except $S$. barracuda, these plots revealed that zero values did not form a natural part of a continuous distribution with positive values (Fig. 2). Therefore, we separately treated occurrence, concentration, and density metrics for each species, each stratum-season, and each year. Finally, to provide data for habitat selection indices, the average density of fish within a stratum was extrapolated to the number of individuals expected within each stratum $\left(\mathrm{P}_{h}\right)$ by adjusting for mangrove area, and subsequently tuned to reflect the proportion of the entire population in our study area, $p \mathrm{P}_{h}$,

$$
p \mathrm{P}_{h}=\frac{\bar{D}_{h} A_{h}}{\sum_{h} \bar{D}_{h} A_{h}}
$$

where $A_{h}$ is the area of fringe habitat per stratum and is equal to $\mathrm{L}_{h} \times 2$.

Statistical analyses. Four metrics of habitat utilization were examined per season-stratum combination for each species: (1) frequency of occurrence, (2) concentration, (3) density, and (4) proportion of the total population. Prior to statistical treatment, data were screened for normality and equal variance and ln-transformed if necessary. When transformation failed to produce data that met the assumptions of analysis of variance (ANOVA), they were rank transformed (RT) and normalized (SAS 1990).

Differences in (species-specific) frequency of occurrence between seasons (strata combined) were examined using Fisher's exact test and differences among strata (seasons combined) using Pearson's chi-squared test. Tests for differences in fish concentration and density values were conducted for each year by applying general linear models (GLM) for unbalanced ANOVA with the factors season, stratum, and their interaction. If the interaction term was non-significant, it was removed and the models were re-run until only significant terms remained. Comparisons of means were performed using $t$-tests in which the experimentwise error rate was set at 0.1 , and comparison-wise error rate was determined using the Bonferroni adjustment.

Selective use of mangrove shoreline strata for each species was examined using chi-squared tests for equal proportions under the null hypothesis that use
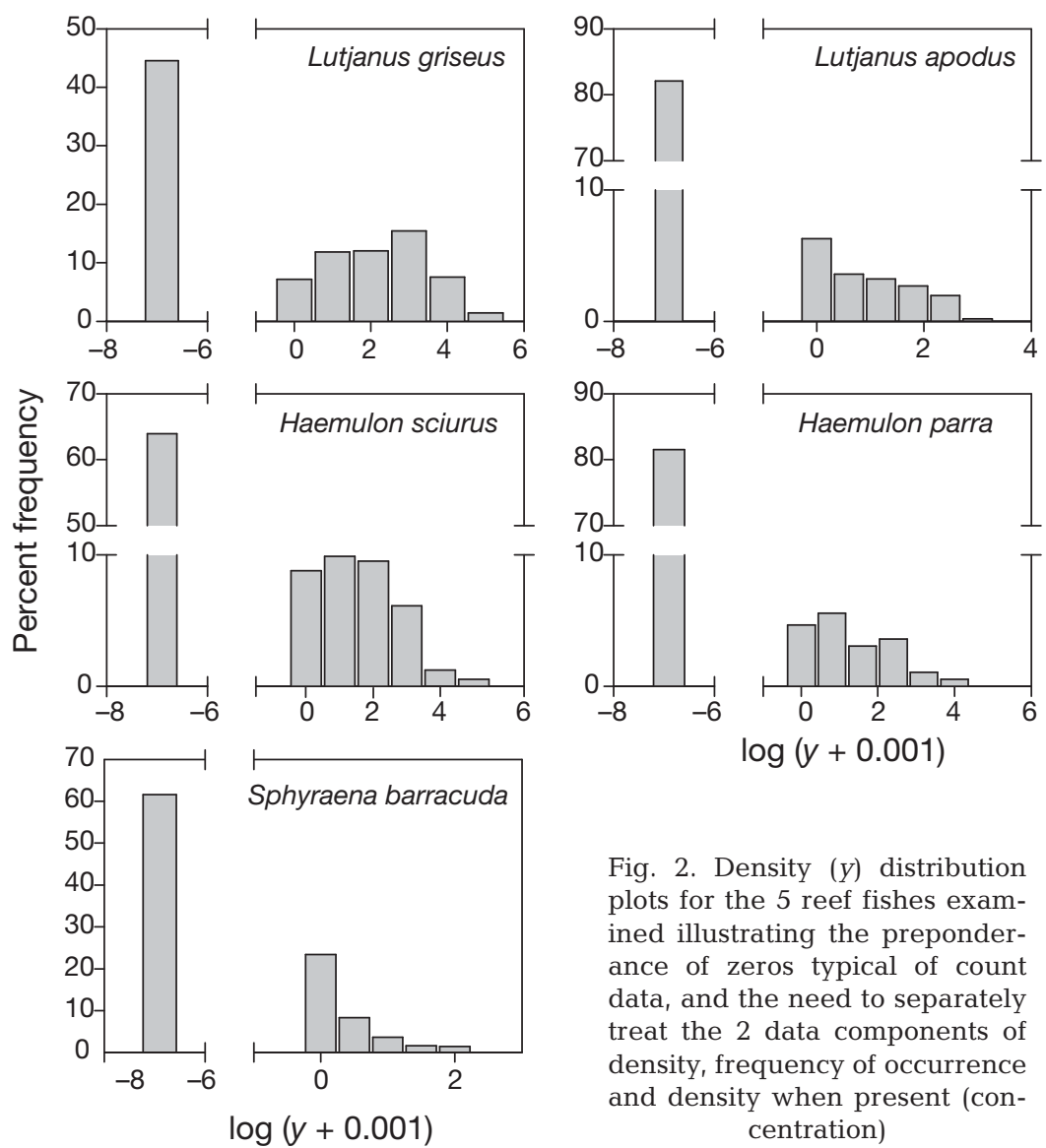

Fig. 2. Density $(y)$ distribution plots for the 5 reef fishes examined illustrating the preponderance of zeros typical of count data, and the need to separately treat the 2 data components of density, frequency of occurrence and density when present (concentration) 
was random, or proportional to availability, i.e. $p \mathrm{P}_{h}=$ $w_{h}$. Selection patterns were elucidated using the standardized selection index $\mathrm{B}_{h}$ :

$$
\mathrm{B}_{h}=\frac{\hat{w}_{h}}{\sum_{h} \hat{w}_{h}}
$$

given $\hat{w}_{h}=p$ (occ.) $/ w_{h}$, where $p$ (occ.) = number of occupied sites in stratum $h$ /total number of occupied transects in the study area. The value of $\mathrm{B}_{h}$ across strata equals 1 , and can be considered the probability that an individual of a given species selected at random will inhabit the stratum in question (Manly et al. 1993). Because we examined 5 strata, random use of a given stratum is indicated by a $\mathrm{B}_{h}$ value of 0.2 . Considering the differences in sampling efficiency and the goals of this work, here we limit our discussion and interpretation to significant results that were consistently observed between years under the assumption that the strongest patterns are the most biologically relevant.

\section{RESULTS}

Sampling precision and efficiency. The study domain encompassed $>500 \mathrm{~km}$ of mangrove shoreline habitat distributed among the 5 cross-shelf strata, of which approximately one-third was contained within the mainland stratum (Table 1). Between 108 and 173 samples were collected during each season giving a total of 557 (Fig. 1b). Between 2000 and 2001, increases in survey effort by $44 \%$ during the dry season and by $60 \%$ during the wet season resulted in precision gains of 15 and $17 \%$, respectively. IRE values indicated gains in precision from stratification in all but the 2001

Table 1. Length $(\mathrm{km})$ of mangrove shoreline $\left(\mathrm{L}_{h}\right)$, proportion of mangrove shoreline present (weighting factor, $w_{h}$ ), and the proportion of samples (visual transects) allocated to each stratum $h$. ML: mainland; IS: island; LB: landbridge; LK: leeward key; WK: windward key during the dry and wet season sampling periods of 2000 and 2001. The proportional allocation of samples per stratum for $2001 \mathrm{w}$ (opt) was based on estimates derived from 2000 analyses. Index of relative efficiency (IRE) values $>1$ indicate precision gained from stratification. CV: coefficient of variation of population estimates (species combined)

\begin{tabular}{|c|c|c|c|c|c|c|c|c|}
\hline \multirow{2}{*}{ Stratum } & \multirow{2}{*}{$\mathrm{L}_{h}$} & \multirow{2}{*}{$W_{h}$} & \multicolumn{2}{|c|}{$-2000-$} & \multirow[b]{2}{*}{$\begin{array}{c}\text { Dry } \\
w(\text { opt })\end{array}$} & \multirow[b]{2}{*}{$\begin{array}{c}\text { Wet } \\
w(\mathrm{opt})\end{array}$} & 2001 & \multirow[b]{2}{*}{$\begin{array}{c}\text { Wet } \\
n=173)\end{array}$} \\
\hline & & & $\begin{array}{c}\text { Dry } \\
(\mathrm{n}=113)\end{array}$ & $\begin{array}{c}\text { Wet } \\
\mathrm{n}=108)\end{array}$ & & & $\begin{array}{c}\text { Dry } \\
(\mathrm{n}=163)(\mathrm{n}\end{array}$ & \\
\hline ML & 172.686 & 0.342 & 0.257 & 0.306 & 0.121 & 0.107 & 0.166 & 0.150 \\
\hline IS & 93.408 & 0.185 & 0.124 & 0.120 & 0.256 & 0.124 & 0.184 & 0.127 \\
\hline LB & 89.826 & 0.178 & 0.186 & 0.176 & 0.127 & 0.249 & 0.135 & 0.277 \\
\hline LK & 89.421 & 0.177 & 0.327 & 0.269 & 0.336 & 0.349 & 0.325 & 0.277 \\
\hline WK & 59.194 & 0.117 & 0.106 & 0.130 & 0.160 & 0.171 & 0.190 & 0.168 \\
\hline IRE & & & 1.12 & 1.43 & & & 0.80 & 1.31 \\
\hline $\mathrm{CV}$ & & & 20.5 & 13.3 & & & 17.4 & 11.0 \\
\hline
\end{tabular}

dry season, when samples were disproportionately allocated towards ML and away from LK in response to monitoring needs for the Comprehensive Everglades Restoration Plan (Serafy et al. 2007).

Fish sizes. Length-frequency distributions for each species were unimodal at the mean. The average TL (cm) of fish observed was 14.4 (range: 2.5-38.1) for Lutjanus apodus, 21.0 (1.3-48.9) for L. griseus, 17.5 (2.5-45.7) for Haemulon sciurus, 10.2 (2.5-25.4) for H. parra, and 27.5 (2.5-121.9) for Sphyraena barracuda. The average size of first maturity is $25 \mathrm{~cm}$ fork length (FL) for L. apodus, and the size at first maturity is near $24.7 \mathrm{TL}$ for L. griseus, $25.3 \mathrm{TL}$ for H. sciurus, and 58 FL for S. barracuda (de Sylva 1963, Faunce \& Serafy 2007). Consistent with the generalized life history for these reef fishes, the average size of fish observed in mangroves was always below their respective size of maturity.

Frequency of occurrence. Frequency of occurrence information reveals temporal and spatial aspects of fish distribution. Greater occurrence values were observed during the wet season compared to the dry season for Lutjanus griseus during 2000, Sphyraena barracuda during 2001, and L. apodus during both years. In contrast, the 2 grunt species never exhibited seasonal differences in occurrence (Table 2). All 5 species occurred in significantly different proportions among strata. L. griseus and S. barracuda were observed in $>20 \%$ of samples within each stratum, indicating they are more widely distributed than the remaining pecies.

Concentration. Unlike patterns in frequency of currence, no species exhibited consistent yearly differences in concentration values between seasons or among strata (Table 2). Concentration values exhibited 2 patterns among species; Lutjanus apodus and Sphyraena barracuda were present in small groups (the former in $<6$ ind. group ${ }^{-1}$ and the latter in $<3$ ind. group $^{-1}$ ) while the other species were more gregarious.

Density. Densities of Lutjanus apodus and Sphyraena barracuda were consistently higher during the wet seasons than during the dry seasons, and this pattern was consistent where differences were found among the other species (Table 2). All 5 species exhibited significantly different density values among strata, and these were consistent between years for all fishes except $S$. barracuda. Where significant differences occurred, density was highest within the LK or WK strata and tended to be lowest within the ML stratum. 
Table 2. Metrics of mangrove habitat utilization and results of statistical tests for 5 reef fishes inhabiting mangrove shorelines habitats in the study domain. Metrics include: frequency of occurrence, expressed as the proportion of transects that contained $\geq 1$ ind.; concentration (i.e. density per $60 \mathrm{~m}^{2}$ transect when the focal species was present); and density of individuals (60 $\mathrm{m}^{-2}$, see 'Materials and methods, Data treatment' for details). Densities are averaged across either seasons or strata. Bold: significant. Letters denote significantly different groups based on post hoc pairwise comparisons where a $>$ b $>$ c. See Table 1 for stratum abbreviations

\begin{tabular}{|c|c|c|c|c|c|c|c|c|c|c|}
\hline \multirow{2}{*}{ Species } & \multirow{2}{*}{ Year } & \multirow[b]{2}{*}{$\mathrm{p}$} & \multirow{2}{*}{$\begin{array}{c}\text { Season } \\
\text { Dry }\end{array}$} & \multirow[b]{2}{*}{ Wet } & \multirow[b]{2}{*}{$\mathrm{p}$} & \multicolumn{3}{|c|}{ - Stratum } & \multirow[b]{2}{*}{ LK } & \multirow[b]{2}{*}{ WK } \\
\hline & & & & & & ML & $\overline{\text { IS }}$ & $\begin{array}{l}\text { West-East } \\
\text { LB }\end{array}$ & & \\
\hline \multicolumn{11}{|c|}{ Occurrence (prop. positive) ${ }^{1}$} \\
\hline \multirow{2}{*}{ Lutjanus griseus } & 2000 & 0.010 & 45.1 & 62.9 & 0.001 & 20.9 & 59.2 & 70.0 & 66.7 & 69.2 \\
\hline & 2001 & 0.079 & 51.5 & 61.2 & 0.001 & 22.6 & 46.1 & 62.8 & 68.3 & 68.3 \\
\hline \multirow[t]{2}{*}{ Lutjanus apodus } & 2000 & 0.001 & 7.9 & 32.4 & 0.003 & 12.9 & 7.4 & 10.0 & 31.8 & 34.6 \\
\hline & 2001 & 0.019 & 11.6 & 21.4 & 0.001 & 3.7 & 3.8 & 8.5 & 24.7 & 35.0 \\
\hline \multirow[t]{2}{*}{ Haemulon sciurus } & 2000 & 0.092 & 30.1 & 41.7 & 0.001 & 6.4 & 11.1 & 40.0 & 60.6 & 61.5 \\
\hline & 2001 & 0.258 & 33.1 & 39.3 & 0.001 & 5.6 & 17.3 & 27.1 & 50.5 & 66.7 \\
\hline \multirow[t]{2}{*}{ Haemulon parra } & 2000 & 0.216 & 14.2 & 21.3 & 0.001 & 4.8 & 7.4 & 5.0 & 36.4 & 30.8 \\
\hline & 2001 & 0.053 & 14.7 & 23.1 & 0.001 & 01.9 & 01.9 & 01.4 & 32.7 & 46.7 \\
\hline \multirow{2}{*}{ Sphyraena barracuda } & 2000 & 0.080 & 38.9 & 50.9 & 0.279 & 40.3 & 29.6 & 45.0 & 51.5 & 53.8 \\
\hline & 2001 & 0.001 & 18.4 & 49.1 & 0.049 & 24.5 & 23.1 & 32.8 & 39.6 & 45.0 \\
\hline \multicolumn{11}{|l|}{ Concentration $^{2}$} \\
\hline \multirow[t]{2}{*}{ Lutjanus griseus } & 2000 & 0.053 & 36.5 & 14.1 & 0.617 & 21.4 & 33.8 & 23.5 & 27.8 & 20.0 \\
\hline & 2001 & 0.867 & 19.8 & 12.4 & 0.090 & 10.5 & 26.0 & 15.4 & 19.6 & 9.1 \\
\hline \multirow[t]{2}{*}{ Lutjanus apodus } & 2000 & 0.267 & 2.7 & 3.3 & 0.120 & 1.9 & 2.0 & 1.2 & 4.2 & 5.5 \\
\hline & 2001 & 0.073 & 1.6 & 2.5 & 0.155 & 1.0 & 0.5 & 1.5 & 3.6 & 3.5 \\
\hline \multirow[t]{2}{*}{ Haemulon sciurus } & 2000 & 0.734 & 23.6 & 18.6 & 0.051 & 4.0 & 25.0 & 12.7 & 29.8 & 34.1 \\
\hline & 2001 & 0.402 & 16.7 & 9.8 & 0.159 & 16.7 & 19.5 & 6.5 & 11.3 & 12.4 \\
\hline \multirow[t]{2}{*}{ Haemulon parra } & 2000 & 0.271 & 6.7 & 3.5 & 0.569 & 3.2 & 0.8 & 7.0 & 11.1 & 3.4 \\
\hline & 2001 & 0.036 & $5.7^{\mathrm{b}}$ & $6.6^{\mathrm{a}}$ & 0.057 & 10.0 & 9.5 & 0.5 & 6.1 & 4.4 \\
\hline \multirow[t]{2}{*}{ Sphyraena barracuda } & 2000 & 0.059 & 1.7 & 1.9 & 0.644 & 1.6 & 1.8 & 1.4 & 2.4 & 1.7 \\
\hline & 2001 & 0.011 & $1.2^{\mathrm{b}}$ & $1.8^{\mathrm{a}}$ & 0.013 & 1.5 & 1.6 & $1.2^{\mathrm{b}}$ & $2.0^{\mathrm{a}}$ & $1.2^{\mathrm{b}}$ \\
\hline \multicolumn{11}{|l|}{ Density $^{3}$} \\
\hline \multirow[t]{2}{*}{ Lutjanus griseus } & 2000 & 0.179 & 21.3 & 11.5 & 0.001 & $3.4^{\mathrm{b}}$ & $24.6^{\mathrm{a}}$ & $19.5^{\mathrm{a}}$ & $20.0^{\mathrm{a}}$ & $14.5^{\mathrm{a}}$ \\
\hline & 2001 & 0.297 & 11.2 & 8.4 & 0.001 & $2.2^{\mathrm{b}}$ & $14.9^{\mathrm{a}}$ & $9.6^{\mathrm{a}}$ & $16.1^{\mathrm{a}}$ & $6.4^{\mathrm{a}}$ \\
\hline \multirow[t]{2}{*}{ Lutjanus apodus } & 2000 & 0.001 & $0.2^{\mathrm{b}}$ & $1.4^{\mathrm{a}}$ & 0.001 & $0.5^{\mathrm{b}}$ & $0.1^{b}$ & $0.1^{\mathrm{b}}$ & $1.8^{\mathrm{a}}$ & $1.5^{\mathrm{a}}$ \\
\hline & 2001 & 0.002 & $0.2^{\mathrm{b}}$ & $0.7^{\mathrm{a}}$ & 0.001 & $0.0^{\mathrm{b}}$ & $0.0^{\mathrm{b}}$ & $0.1^{\mathrm{b}}$ & $0.9^{\mathrm{a}}$ & $1.3^{\mathrm{a}}$ \\
\hline \multirow[t]{2}{*}{ Haemulon sciurus } & 2000 & 0.021 & $7.1^{\mathrm{b}}$ & $9.0^{\mathrm{a}}$ & 0.001 & $0.3^{\mathrm{c}}$ & $2.6^{\mathrm{bc}}$ & $4.7^{\mathrm{b}}$ & $15.6^{\mathrm{a}}$ & $16.9^{\mathrm{a}}$ \\
\hline & 2001 & 0.293 & 4.3 & 4.4 & 0.001 & $2.7^{b}$ & $2.7^{\mathrm{b}}$ & $1.6^{\mathrm{b}}$ & $5.7^{\mathrm{a}}$ & $9.2^{\mathrm{a}}$ \\
\hline \multirow[t]{2}{*}{ Haemulon parra } & 2000 & 0.149 & 1.2 & 1.0 & 0.001 & $0.3^{\mathrm{c}}$ & $0.1^{\mathrm{bc}}$ & $0.3^{\mathrm{bc}}$ & $3.8^{\mathrm{a}}$ & $1.0^{\mathrm{ab}}$ \\
\hline & 2001 & 0.001 & $0.5^{\mathrm{b}}$ & $1.5^{\mathrm{a}}$ & 0.001 & $0.4^{\mathrm{b}}$ & $0.4^{\mathrm{b}}$ & $0.0^{\mathrm{b}}$ & $1.9^{\mathrm{a}}$ & $2.5^{\mathrm{a}}$ \\
\hline Sphyraena barracuda & 2000 & 0.016 & $0.6^{\mathrm{b}}$ & $1.0^{\mathrm{a}}$ & 0.124 & 0.6 & 0.5 & 0.6 & 1.2 & 1.0 \\
\hline & 2001 & 0.001 & $0.2^{\mathrm{b}}$ & $0.9^{\mathrm{a}}$ & 0.005 & $0.4^{\mathrm{b}}$ & $0.5^{\mathrm{ab}}$ & $0.4^{\mathrm{b}}$ & $1.0^{\mathrm{a}}$ & $0.6^{\mathrm{ab}}$ \\
\hline
\end{tabular}

Habitat selection. Species-specific patterns in fish use of mangrove shorelines was observed. Use was nonrandom during all 4 seasons for Lutjanus griseus, L. apodus, and Haemulon parra, during 3 seasons for $H$. sciurus, and only during the wet seasons for Sphyraena barracuda (Table 3). Three patterns in habitat use were observed from selection indices. First, L. griseus exhibited season-specific selection patterns. During the dry season, it was almost twice as likely to use islands than any other stratum, while during the wet seasons, L. griseus selected the LK stratum (Fig. 3a). Second, S. barracuda was distributed among strata randomly during the dry seasons, but exhibited positive selection for the LK during the wet seasons (Fig. 3b). The remaining species, L. apodus, H. sciurus, and H. parra, selected for the LK and/or WK and against the remaining strata during every season (Fig. 3c-e). 
Table 3. Allocation of the available mangrove habitat $\left(w_{h}\right)$ and individuals in the population of reef fishes $\left(p \mathrm{P}_{h}\right)$ among cross-shelf strata (abbreviations follow Table 1)

\begin{tabular}{|c|c|c|c|c|c|c|c|}
\hline $\begin{array}{l}\text { Species } \\
\quad \text { Season Year }\end{array}$ & ML & IS & LB & $\begin{array}{l}\text { Stratum } \\
\text { LK }\end{array}$ & WK & $\chi^{2}$ & $\mathrm{p}$ \\
\hline $\begin{array}{l}W_{h}(\text { expected } \\
\text { proportion) } p \mathrm{P}_{h}\end{array}$ & 0.342 & 0.185 & 0.178 & 0.177 & 0.117 & & \\
\hline \multicolumn{8}{|l|}{ Lutjanus griseus } \\
\hline Dry 2000 & 0.085 & 0.372 & 0.219 & 0.250 & 0.073 & 43.9 & $<0.001$ \\
\hline Wet 2000 & 0.066 & 0.170 & 0.278 & 0.275 & 0.211 & 41.0 & $<0.001$ \\
\hline Dry 2001 & 0.120 & 0.345 & 0.223 & 0.250 & 0.063 & 34.9 & $<0.001$ \\
\hline Wet 2001 & 0.066 & 0.182 & 0.228 & 0.385 & 0.140 & 48.5 & $<0.001$ \\
\hline \multicolumn{8}{|l|}{ Lutjanus apodus } \\
\hline Dry 2000 & 0.000 & 0.216 & 0.046 & 0.365 & 0.373 & 120.4 & $<0.001$ \\
\hline Wet 2000 & 0.267 & 0.012 & 0.031 & 0.467 & 0.223 & 87.1 & $<0.001$ \\
\hline Dry 2001 & 0.067 & 0.000 & 0.043 & 0.493 & 0.398 & 174.6 & $<0.001$ \\
\hline Wet 2001 & 0.026 & 0.033 & 0.073 & 0.426 & 0.443 & 173.5 & $<0.001$ \\
\hline \multicolumn{8}{|c|}{ Haemulon sciurus } \\
\hline Dry 2000 & 0.009 & 0.085 & 0.094 & 0.550 & 0.262 & 138.4 & $<0.001$ \\
\hline Wet 2000 & 0.017 & 0.060 & 0.162 & 0.404 & 0.357 & 117.8 & $<0.001$ \\
\hline Dry 2001 & 0.326 & 0.143 & 0.096 & 0.283 & 0.152 & 12.2 & 0.015 \\
\hline Wet 2001 & 0.000 & 0.218 & 0.060 & 0.272 & 0.450 & 142.5 & $<0.001$ \\
\hline \multicolumn{8}{|l|}{ Haemulon parra } \\
\hline Dry 2000 & 0.000 & 0.040 & 0.111 & 0.740 & 0.109 & 227.2 & $<0.001$ \\
\hline Wet 2000 & 0.211 & 0.000 & 0.010 & 0.635 & 0.144 & 158.5 & $<0.001$ \\
\hline Dry 2001 & 0.420 & 0.000 & 0.000 & 0.454 & 0.125 & 81.6 & $<0.001$ \\
\hline Wet 2001 & 0.000 & 0.145 & 0.003 & 0.396 & 0.456 & 177.6 & $<0.001$ \\
\hline \multicolumn{8}{|c|}{ Sphyraena barracuda } \\
\hline Dry 2000 & 0.245 & 0.232 & 0.190 & 0.268 & 0.062 & 11.3 & 0.023 \\
\hline Wet 2000 & 0.315 & 0.062 & 0.122 & 0.291 & 0.209 & 24.8 & $<0.001$ \\
\hline Dry 2001 & 0.389 & 0.081 & 0.248 & 0.132 & 0.149 & 11.3 & 0.023 \\
\hline Wet 2001 & 0.187 & 0.189 & 0.096 & 0.402 & 0.124 & 39.5 & $<0.001$ \\
\hline
\end{tabular}

that the species examined spawn primarily during the wet season summer months at oceanic locations, the patterns in frequency of occurrence exhibited by juvenile reef fishes indicate greater numbers near source populations (de Sylva 1963). This pattern is in support of the 'waiting room hypothesis', whereby nearshore environments act to capture (perhaps excess) recruits from the coral reef, and, since individuals eventually migrate to the adult populations, aid to buffer against poor recruitment years (Parrish 1989).

In contrast to patterns of occurrence, the majority of reef fishes did not exhibit consistent patterns in concentration either between seasons or among strata. Instead, group sizes for reef fishes were species-specific. Group size may reflect the ecological role mangroves play in the lives of individual species. For example, Verweij et al. (2006) found that Haemulon flavolineatum within mangroves fed as solitary individuals but rested in groups. Limited data on group size exist for the species we examined. As with our study, Lutjanus apodus were most commonly observed as solitary individuals (group size $=1$ ) within coastal mangroves of the Isle of Youth, Cuba (Valdés-Muñoz

\section{DISCUSSION}

While most prior studies of fishes inhabiting mangroves have compared density from $<10$ locations, ours is the first to compare multiple metrics of use among entire mangrove shorelines located along a cross-shelf gradient. The separate examination of patterns in frequency of occurrence and concentration yielded information that would otherwise have been lost if we had only compared fish use of mangroves using mean density. Based on patterns of significance, we conclude that density patterns were driven primarily by differences in the distribution of fishes, and not by the number of fish present when encountered.

Despite its utility, use of occurrence and concentration data toward assessing habitat utilization is rare in the relevant literature, making comparisons difficult. In our study, species-specific frequency of occurrence patterns were clear. When significant differences were found, the likelihood of observing the focal reef fishes within fringing mangrove forests was always greatest during the wet season and within the eastern-located shorelines (especially the LK and WK strata). Given
\& Mochek 2001). Similarly, Sphyraena barracuda has been observed in groups of 1 or 2 ind. sample $\mathrm{e}^{-1}$ in our study and as solitary individuals in $82 \%$ of encounters by Paterson (1998) in a variety of habitats of the South Caicos Islands. Patterns between studies vary for H. sciurus. This species was observed as solitary individuals in Cuba by Valdés-Muñoz \& Mochek (2001) about $80 \%$ of the time, whereas in our study, solitary fish were observed in only $12 \%$ of samples. Identification of factors that underlie differences in group sizes warrants further research.

Published density values for fishes inhabiting mangroves are more widely available than either frequency of occurrence or concentration. The seasonal and location-specific data collected here, combined with local (south Florida) and regional (western Atlantic) trends in species-specific densities may be used to identify broad patterns of mangrove habitat use. Our finding that Lutjanus apodus occupies mangrove shorelines in greater densities during the summer months was not found within similar habitats of Puerto Rico (Rooker \& Dennis 1991). South Florida may represent marginal mangrove habitat for this species, as our 

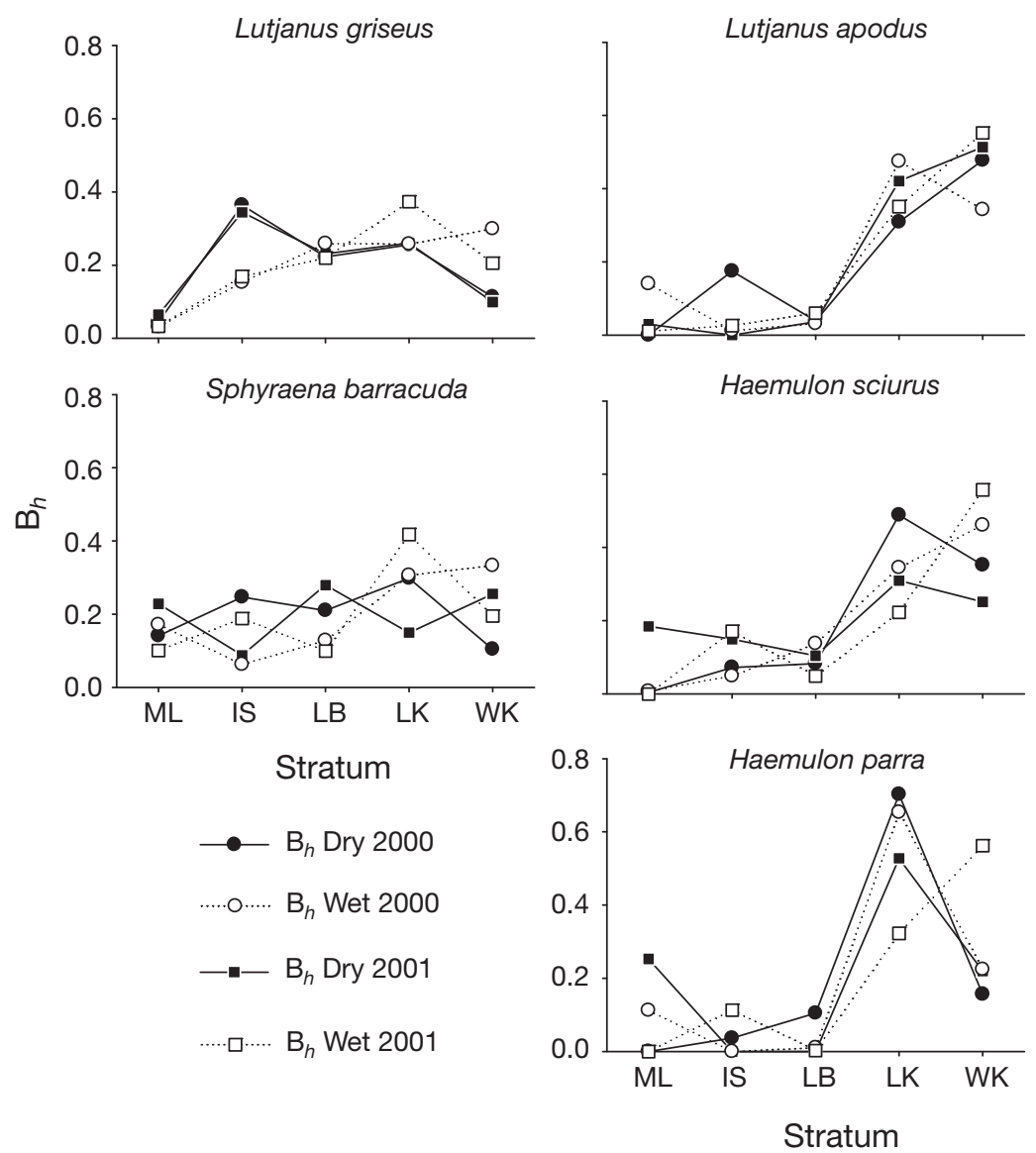

Fig. 3. Summary of standardized selection index values (i.e. $B_{h}$ after Manley et al. 1993) for reef fishes inhabiting 5 mangrove shoreline strata (abbreviations follow Table 1). Strata are presented along the $x$-axis according to their longitudinal position from west (left) to east (right). Consistent $B_{h}$ values of 0.2 would indicate a random distribution of individuals among strata

density values within the preferred Keys strata are 10 times lower than values from Curaçao and northeastern Cuba (Claro \& García-Arteaga 1993, Nagelkerken et al. 2000a, Cocheret de la Morinière et al. 2002), and half the values reported from Bonaire (Nagelkerken et al. 2000b).

Density patterns of Lutjanus griseus contrast with those of $L$. apodus. Instead of exhibiting significantly greater densities during the summer, $L$. griseus densities were similar between seasons. This species also failed to exhibit strong seasonal trends in density within the predominantly freshwater tributaries north and west of our study area (Faunce et al. 2004). Although available information from southeastern Florida indicates that $L$. griseus inhabits eastern Keys mangrove shorelines in greater densities than the western mainland, this species appears to have an affinity for large coastal embayments. For example, although the average density of $L$. griseus within the Keys shorelines is similar to prior data from Florida
(Sheridan 1992, Ley \& McIvor 2001), Mexico (Vega-Cendejas et al. 1994), and northern Cuba (Claro \& García-Arteaga 1993), it is 3 to 7 times greater than values from Curaçao and Bonaire (Nagelkerken et al. 2000a,b, Cocheret de la Morinière et al. 2002).

We found seasonal patterns in grunt density that were different from those reported elsewhere. When significant, the density of Haemulon parra and $H$. sciurus in this study was greater during the summer wet season than during the dry season. In contrast, Rooker \& Dennis (1991) reported greater densities of these species within tropical Puerto Rican mangroves during their dry season. These differences, combined with the inter-annual differences we observed, highlight that the seasonal patterns of mangrove habitat use remain inconclusive for these species. These species also exhibit different density patterns throughout the region. $H$. parra tends to occur in similar densities throughout western Atlantic mangrove shorelines (0.024 to 0.095 fish $\left.\mathrm{m}^{-2}\right)$ whereas $H$. sciurus densities appear more variable throughout the region. In our study, the average density of $H$. sciurus within the Keys shorelines was roughly one-third of that reported from northern Cuba (Claro \& García-Arteaga 1993), 7 times greater then values from northeastern Florida Bay (Ley \& McIvor 2001), and more than 45 times greater than values reported from Bonaire (Nagelkerken et al. 2000b). These results highlight the need for a speciesspecific approach to habitat valuation.

Two species exhibited consistent seasonal density patterns. Sphyraena barracuda and Lutjanus apodus were consistently found in greater densities during the wet seasons. Similar to the grunts, these results for $S$. barracuda contrast findings from Puerto Rico, where seasonal comparisons were non-significant (Rooker \& Dennis 1991). The reasons for the discrepancies between the seasonal data in our study and that of Rooker \& Dennis (1991) are unclear, because $S$. barracuda is a habitat and foraging generalist, able to inhabit turbid estuaries as well as clear-water oceanic lagoons, while preying upon fishes in all types of conditions (Blaber 1982). These biological traits should dictate that this species exhibit little affinity toward either continental or island mangrove systems. Indeed, no obvious trends were evident, as average $S$. barracuda density reported here was nearly 4 -fold less than that observed in Bonaire (Nagelkerken 
et al. 2000b) and 38 times greater than Celestun lagoon, Mexico (Vega-Cendejas et al. 1994).

When density information was extrapolated to the population inhabiting the study area, and expressed in terms of relative use, our data reject the hypothesis that mangrove shorelines located along a cross-shelf gradient are used in accordance with their availability. Rather, our data highlight that patches of mangrove shoreline within the same ecosystem differ in terms of their value as reef fish habitat and cannot be considered homogenous units. Three patterns of selective habitat use emerged in this study. The first was a seasonally-specific selection pattern exhibited by Lutjanus griseus, which selected for the easterly LK and WK strata during the summer and the Island stratum during the winter. Starck (1970) suggested that this species makes seasonal movements offshore during the summer and inshore during the winter, and our results provide much-needed quantitative data in support of such a movement pattern.

The second pattern was exhibited by Sphyraena barracuda, which is the only species we examined with a pandemic distribution, and was randomly distributed among mangrove shorelines during the dry seasons. $S$. barracuda shares a similar life-history to the other species we examined; however, this species differs in that individuals attack one another and form social hierarchies in space-limited environments (de Sylva 1963). Given that mangroves are among the most space-limited habitats available to juvenile reef fishes in southern Florida, yet undiscovered environmental pressures in southeastern Florida during the dry winter months may select for stronger territoriality in $S$. barracuda and result in their less aggregated distribution in space during this time.

The final and most common selection pattern was exhibited by Lutjanus apodus, Haemulon sciurus, and $H$. sciurus that consistently selected for the eastern LK and WK strata and largely avoided the most westernlocated stratum year-round. This pattern, shared by L. griseus during the wet seasons, is consistent with the commonly observed pattern of declining species richness and total catch with increasing distance inland from creek mouths and oceanic inlets worldwide (e.g. Quinn 1980, Kimani et al. 1996, Hajisamae \& Chou 2003). Patterns of habitat use may be due to differences in accessibility (sites located within home ranges are used more than those within more rare long-distance movement) or suitability. Faunce \& Serafy (2007) and Serafy et al. (2007) examined use of mangroves within our study area with respect to environmental factors and ontogeny. These studies found that fish body size of $L$. griseus and $H$. sciurus increased with distance from inlet into the bay, water depth was greatly related to fish use, and there was no correlation between depth and distance from oceanic inlet. These results suggest that proximity, rather than suitability, drives the pattern of habitat use. What our comparisons of use versus availability demonstrate here is that in the case of southeastern Florida, these spatial patterns are due to selective processes, and because the fishes examined are not planktonic, we can reasonably assume that patterns in use result from active selection. Clearly mangroves located along oceanic Keys shorelines, within inlets and channels, and along immediately leeward shorelines are of the greatest use to the reef fishes examined, with the added caveat that large embayments are important to L. griseus during the winter months.

The data we present illustrate the error of treating habitats as homogenous ecotones. Rather, because species-specific selection patterns among different mangrove shoreline types incorporate information on use relative to habitat area, they provide a means to assign importance values to different patches of the same habitat type. These data are relevant when management resources are limited and decision makers must decide between preservation of one resource over another. Even in southeastern Florida (Monroe north to Martin County), where financial resources are greater than in many locations where mangroves occur, mangrove acreage declined by $11 \%$ from 1987 to 2000 (Ueland 2005). These trends are reflected worldwide, as deforestation and overexploitation of fish and shellfish have been ranked as 'high-level threats' to mangrove forests, whose global coverage has declined by $33 \%$ over the last 50 years (Alongi 2002). Our findings provide new quantitative data on the role of mangroves as fish habitat and demonstrate that their contribution toward enhanced populations of adult stocks of reef fishes is not a simple function of the amount of habitat area (availability), but is rather heterogeneously proportioned within embayments and changes with species and season.

Acknowledgements. This work was funded by the Perry Institute for Marine Science and Biscayne National Park. Thanks to Captain M. South, D. Lairson, J. Barimo, D. Kieckbusch, and B. Teare, who endured physically demanding conditions with grace. We also acknowledge M. Ortiz and G. Diaz, who kindly and patiently explained some of the mathematical intricacies presented in this paper.

\section{LITERATURE CITED}

Adams AJ, Dahlgren CP, Kellison GT, Kendall MS and others (2006) Nursery function of tropical back-reef systems. Mar Ecol Prog Ser 318:287-301

Alongi DM (2002) Present state and future of the world's mangrove forests. Environ Conserv 29:331-349

Ault JS, Diaz GA, Smith SG, Luo J, Serafy JE (1999) An efficient sampling survey design to estimate pink shrimp population abundance in Biscayne Bay, Florida. N Am J Fish Manag 19:696-712 
Bardach JE (1959) The summer standing crop of fish on a shallow Bermuda reef. Limnol Oceanogr 4:77-85

Bell JD, Craik GJS, Pollard DA, Russell BC (1985) Estimating length frequency-distributions of large reef fish underwater. Coral Reefs 4:41-44

Blaber SJM (1982) The ecology of Sphyraena barracuda (Osteichthyes: Perciformes) in the Kosi system with notes on the Sphyraenidae of other Natal estuaries. South Afr J Zool 17:171-176

Claro R, García-Arteaga JP (1993) Fish community structure on mangroves from the Insular Group Sabana-Camaguey, Cuba. Avicennia 10:60-83

Cocheret de la Morinière E, Pollux BJA, Nagelkerken I, van der Velde G (2002) Post-settlement life cycle migration patterns and habitat preference of coral reef fish that use seagrass and mangrove habitats as nurseries. Estuar Coast Shelf Sci 55:309-321

Dahlgren CP, Eggleston DB (2000) Ecological processes underlying ontogenetic habitat shifts in a coral reef fish. Ecology 81:2227-2240

de Sylva DP (1963) Systematics and life history of the great barracuda, Vol 1. University of Miami Press, Coral Gables, FL

Dorenbosch M, van Riel MC, Nagelkerken I, van der Velde G (2004) The relationship of reef fish densities to the proximity of mangrove and seagrass nurseries. Estuar Coast Shelf Sci 60:37-48

Faunce CH, Serafy JE (2006) Mangroves as fish habitat: 50 years of field studies. Mar Ecol Prog Ser 318:1-18

Faunce CH, Serafy JE (2007) Nearshore habitat use by gray snapper (Lutjanus griseus) and bluestriped grunt (Haemulon sciurus): environmental gradients and ontogenetic shifts. Bull Mar Sci 80:473-495

Faunce CH, Serafy JE, Lorenz JJ (2004) Density-habitat relationships of mangrove creek fishes within the southeastern saline Everglades (USA), with reference to managed freshwater releases. Wetl Ecol Manag 12:377-394

Fletcher D, Mackenzie D, Villouta E (2005) Modeling skewed data with many zeros: a simple approach combining ordinary and logistic regression. Environ Ecol Stat 12:45-54

Hajisamae S, Chou LM (2003) Do shallow water habitats of an impacted coastal strait serve as nursery grounds for fish? Estuar Coast Shelf Sci 56:281-290

Jones GP, Caley MJ, Munday PL (2002) Rarity in coral reef fish communities. In: Sale PF (ed) Coral reef fishes: dynamics and diversity in a complex ecosystem. Academic Press, San Diego, CA, p 81-102

Kimani EN, Mwatha GK, Wakwabi EO, Ntiba JM, Okoth BK (1996) Fishes of a shallow tropical mangrove estuary, Gazi, Kenya. Mar Freshw Res 47:857-868

Ley JA, McIvor CC (2001) Linkages between estuarine and reef fish assemblages: enhancement by the presence of well-developed mangrove shorelines. In: Porter JW, Porter KG (eds) The Everglades, Florida Bay, and coral reefs of the Florida Keys: an ecosystem sourcebook. CRC Press, Boca Raton, FL, p 539-562

Lindeman KC, Diaz GA, Serafy JE, Ault JS (1998) A spatial framework for assessing cross-shelf habitat use among newly settled grunts and snappers. Proc Gulf Caribb Fish Inst 50:385-416

Manly BFJ, McDonald LL, Thomas DL (1993) Resource selection by animals: statistical design and analysis for field studies. Chapman \& Hall, London

Martino EJ, Able KW (2003) Fish assemblages across the marine to low salinity transition zone of a temperate estuary. Estuar Coast Shelf Sci 56:969-987

Mumby PJ, Edwards AJ, Arias-Gonzales JE, Lindeman KC and others (2004) Mangroves enhance the biomass of coral reef fish communities in the Caribbean. Nature 427 : 533-536

Nagelkerken I, Dorenbosch M, Verberk WCEP, Cocheret de la Morinière E, van der Velde G (2000a) Importance of shallow-water biotopes of a Caribbean bay for juvenile coral reef fishes: patterns in biotope association, community structure and spatial distribution. Mar Ecol Prog Ser 202:175-192

Nagelkerken I, van der Velde G, Gorissen MW, Meijer GJ, van't Hof T, Den Hartog C (2000b) Importance of mangroves, seagrass beds and the shallow coral reef as a nursery for important coral reef fishes, using a visual census technique. Estuar Coast Shelf Sci 51:31-44

Parrish JD (1989) Fish communities of interacting shallowwater habitats in tropical oceanic regions. Mar Ecol Prog Ser 58:143-160

Paterson SE (1998) Group occurrence of great barracuda (Sphyraena barracuda) in the Turks and Caicos Islands. Bull Mar Sci 63:633-638

Pollux BJA, Verberk WCEP, Dorenbosch M, Cocheret de la Morinière EC, Nagelkerken I, van der Velde G (2007) Habitat selection during settlement of three Caribbean coral reef fishes: indications for directed settlement to seagrass beds and mangroves. Limnol Oceanogr 52:903-907

Quinn NJ (1980) Analysis of temporal changes in fish assemblages in Serpentine Creek, Queensland. Environ Biol Fishes 5:117-133

Rooker JR, Dennis GD (1991) Diel, lunar and seasonal changes in a mangrove fish assemblage off southwestern Puerto Rico. Bull Mar Sci 49:684-698

SAS (1990) SAS User's Guide: Statistics. SAS Institute, Cary, $\mathrm{NC}$

Serafy JE, Faunce CH, Lorenz JJ (2003) Mangrove shoreline fishes of Biscayne Bay, Florida. Bull Mar Sci 72:161-180

Serafy JE, Valle M, Faunce CH, Luo J (2007) Species-specific patterns of fish abundance and size along a subtropical mangrove shoreline: an application of the delta approach. Bull Mar Sci 80:609-624

Sheridan PF (1992) Comparative habitat utilization by estuarine macrofauna within the mangrove ecosystem of Rookery Bay, Florida. Bull Mar Sci 50:21-39

Starck WE II (1970) Biology of the gray snapper, Lutjanus griseus (Linnaeus), in the Florida Keys. In: Starck WE II, Schroeder RE (eds) Investigations on the gray snapper, Lutjanus griseus, Vol 10. University of Miami Press, Coral Gables, FL, p 11-150

Stefansson G (1996) Analysis of groundfish survey abundance data: combining the GLM and delta approaches. ICES J Mar Sci 53:577-588

Thomas DL, Taylor EJ (2006) Study designs and tests for comparing resource use and availability II. J Wildl Manag 70: 324-336

Ueland JS (2005) Ecological modeling and human dimensions of mangrove change in Florida. PhD thesis. Florida State University, Tallahassee, FL

Valdés-Muñoz E, Mochek AD (2001) Behavior of marine fishes of the Cuban shelf. In: Claro R, Lindeman KC, Parenti LR (eds) Ecology of the marine fishes of Cuba. Smithsonian Institution Press, Washington, DC, p 73-114

Vega-Cendejas ME, Ordóñez U, Hernández M (1994) Daynight variation of fish population in the mangrove of Celestun lagoon, Mexico. Int J Ecol Environ Sci 20:99-108

Verweij MC, Nagelkerken I, Wartenbergh SLJ, Pen IR, van der Velde G (2006) Caribbean mangroves and seagrass beds as daytime feeding habitats for juvenile French grunts, Haemulon flavolineatum. Mar Biol 149: 1291-1299

Submitted: December 19, 2006; Accepted: September 3, 2007 Proofs received from author(s): February 29, 2008 